\title{
Intra Household Labour Distribution and Role of Women in Family Decision Making Process
}

\author{
Md. Shafiqul Islam ${ }^{1}$ \\ Assistant ProfessorCenter for Sustainable Development, University of Liberal Arts Bangladesh, Dhaka, \\ Bangladesh
}

\begin{abstract}
A study on intra-household labor distribution and role of women in family decision making process was conducted over a period of 3 months with respect to sample 1 (S-1) single family with two children (children age around 12 years), sample 2 (S-2) joint family with husband and wife, brother-sister, father mother and children, sample 3 (S-3) joint family, husband-wife, brother-sister, father-mother and children (with primary education in any one).Total 30 families (10 from each sample) were assessed in terms of labor distribution in productive, reproductive, community \& other works, role of women in family decision making process and work load after joining in to SHABGE-DFID project. Male members from all samples were spent more time in productive works and they have negligible role in reproductive works. The female members were spent more time in reproductive works. They were also spent remarkable time in productive works and little bit in community works. The female members from sample 1 were spent more time for various works in a day than other samples. The female members in sample 3 were spent less time than other samples and it is due to their consciousness (for their primary education). Among all the samples workload increased after joining in SHABGE-DFID project. They were managed this work load by taking help from husband and children (incase of sample $2 \& 3)$. After joining in the SHABGE-DFID project $50 \%$ female from sample (1\&2) were took part in family decision making process i.e. they were involved in family decision making process actively. After completion of the project the family members would be aware about their individual role and women could be take part in family decision making process more actively.
\end{abstract}

Key words: Intra; Household; Women empowerment; Family decision; Productive and reproductive works; Farmer Field School

\section{Introduction}

Bangladesh lies in the north eastern part of South Asia between $20^{\circ} 34^{\prime}$ and $26^{\circ} 38^{\prime}$ north latitude and $88^{0} 1^{\prime}$ and $92^{\circ} 41^{\prime}$ east longitude. Bangladesh is a densely populated country in the south Asia. Women in Bangladesh constitute $48 \%$ of the total population of which $86 \%$ are illiterate. The life of a woman in Bangladesh is therefore dominated by the social system. Such a system upholds a rigid division of labor that controls women's mobility, roles and responsibility, and sexuality. Traditionally, a woman in Bangladesh derives her status from her family. Her role includes the maintenance of her family as a social institution and as an economic entity. Most importantly, through child bearing and child rearing, she ensures the existence of succeeding generations. Increasingly, however, women's roles, responsibility, and mobility are changing due to unrelenting poverty and the gradual attrition of the familial umbrella of support.

Women in rural Bangladesh are major but largely unrecognized contributors to agricultural and economic productivity. Half of these human resources consist of women and the majority of them $(92.05 \%)$ live in rural areas (Islam 1977).

There is a close connection between access to resources and control over their use, and the power to make decisions; but they are distinguishable issues. Within the household, decisions are taken on the sale of products, land, or animals, the production process itself (what to produce, when, where, why, how), development of the infrastructure, whether to save or invest, and whether some members of the household should work on the farm or take other jobs outside the household. Productive activities can help to strengthen the position of women in the decision-making process within the household. Gender is an important dimension for the analysis and eradication of poverty (Kabeer 1994).

Pragmatic indication across countries suggests that the number of households below the poverty line is significantly higher for female- than for male headed households. Over 95 percent of female-headed households in Bangladesh are considered to fall below the poverty line (UNDP 1996). In Bangladesh, official estimates suggest that less than a tenth of households are headed by women (BBS 1996), but the actual proportion could be around 20-30 percent (Afsar 1997; MOWCA 1997). Bangladesh's NGOs provide microcredit to some 8 million people, mostly women (World Bank 1998) and their number has increased substantially over the years. 
Intra Household Labour Distribution and Role of Women In Family Decision Making Process

Women have profound knowledge of the plants, animals, and ecological processes around them. Women perform various activities, e.g., collecting, processing, storing, utilization, management, and marketing. Women's roles and responsibilities are pivotal not only to the management of natural resources but also to the management of the domestic economy. However, women's roles are mostly undocumented and unaccounted in the official statistics.

A good number of rural women are also involved in rural construction work. Women workers are found in certain activities traditionally falling within the male domain (e.g., earthwork, construction, and agricultural work in the field). This is particularly the case for landless women who largely belong to the hardcore poor group. It indicates growing economic pressure and erosion of familial support and traditional beliefs and norms regarding women's outside work.

Strengthening Household Access to Bari Gardening and Extension (SHABGE) DFID project also worked with poor homestead farmers in the South-East and North-West regions of the country. The project aimed to work with a total populations of 3,10,000 poor families of which $75 \%$ were women and rest of the participants were men. The main purpose of the project was to improve household food security status of the targeted populations by means of increasing their capacity to manage homestead gardens.

Actually, women in many societies have limited mobility, limited access in land use and land tenure reflects status, inheritance patterns, family and community structure and national policy. Being responsible for various tasks both within and outside the home, they are forced to work a "double day".

Several study also enumerate that rural woman works very long hours tend to 16 hours a day. They do tasks which includes a high degree of physical toil. But they may not have decision making role or rights over land use.

It also refers to access to and control over one's own labour and the benefits of production, which include cash income, food, and other products for home consumption, sales, or exchange. Gendered access to and control over specifically homestead and natural resources often means that women have rights of renewable use (such as harvesting leaves from trees), while men have rights of consumption (harvesting the tree itself, for example). For female heads of household, their access to resources is often limited to those of poorer quality, and the consequence is lower agricultural production levels compared with male heads of household.

The study was carried out to assess the labor distribution system within a household as well as to know the role of women in the family decision making process. The other objectives of the study were to assessed the relative measures of the time spent by individual household; assessed how much workload of women increase after joining in SHABGE-DFID Project and how she managed this increased workload; assessed how an woman played her role in family decision in the previous context and compare the same with an woman who was joined in the project

\section{Methodology}

The study was concentrated in two Upazila under Dinajpur district and the study design was developed in an open-ended iterative process over a period of 3 months. The total 30 Farmer Field Scholl (FFS) members were selected from 210 FFS. The interview was made or designed based on single family, family consists of wife, husband and two/three children (grand father and mother, elderly person), children age around 5-12 years, interested family, primary educated family (any one sample), Agro based family (vegetable, poultry and livestock) land holding 50 decimal (homestead field) and FFS household.

After preliminary \& socioeconomic survey the parameters of potential value for the study were reviewed. Based on the family types of FFS members were categorized in to three groups as follows:

i. $\quad$ Sample (S-1): Single family with two children (children age around 12 years)

ii. $\quad$ Sample (S-2): Joint family, husband-wife, brother-sister, father-mother and children.

iii. $\quad$ Sample (S-3): Joint family, husband-wife, brother-sister, father-mother and children (primary education A partly random, partly purposive sample of 30 FFS farmers household were selected from three types of samples (10 from each sample) for interview based on a standard questionnaire. The instrument used for data collection was semi-structured questionnaire, covering labor distribution in productive, reproductive work, social/community works.

\section{Results \\ 1. DEMOGRAPHY AND POPULATION CHARACTERISTICS}

Demography and population characteristics of the study area includes occupation, age, sex, labor distribution in productive, reproductive, social and other works. The average age of the female respondents were mostly between $13-50$ years (Table I). About $50 \%$ of the total populations were male and remaining female. Among household members $23 \%$ less than 13 years old, $61 \%$ were (13-50) years old and only $12 \%$ were older than 50 years. 
Table I: Average age distribution of FFS family members

\begin{tabular}{|l|l|l|l|l|}
\hline Sample & Sex & \multicolumn{3}{|c|}{ Age group } \\
\hline & & $(5-12)$ years & $(13-50)$ years & $(50+)$ years \\
\hline $\mathrm{S} 1$ & Male $\mathrm{n}=20$ & $10(50)$ & $10(50)$ & \\
$\mathrm{N}=37$ & Female $\mathrm{n}=17$ & $7(41)$ & $10(59)$ & \\
\hline $\mathrm{S} 2$ & Male $\mathrm{n}=23$ & $5(22)$ & $15(65)$ & $3(13)$ \\
$\mathrm{N}=50$ & Female $\mathrm{n}=27$ & $5(19)$ & $14(52)$ & $8(29)$ \\
\hline $\mathrm{S} 3$ & Male $\mathrm{n}=26$ & $6(23)$ & $18(69)$ & $2(8)$ \\
$\mathrm{N}=39$ & Female $\mathrm{n}=13$ & $1(8)$ & $10(78)$ & $2(7)$ \\
\hline All & Male $\mathrm{n}=69$ & $21(47)$ & $43(62)$ & $5(7)$ \\
$\mathrm{N}=126$ & Female $\mathrm{n}=57$ & $13(23)$ & $34(60)$ & $10(10)$ \\
\hline
\end{tabular}

$\mathrm{N}=$ total population

Figure in parenthesis indicate percentage value

Table II: Main occupation of the FFS members

\begin{tabular}{|l|l|l|l|l|l|}
\hline \multicolumn{1}{|c|}{ Sample } & \multicolumn{5}{|c|}{ Occupation } \\
\hline & Agriculture & Labor sale & Housewife & Business & $\begin{array}{l}\text { Study \& } \\
\text { others }\end{array}$ \\
\hline $\begin{array}{l}\text { S1 } \\
\mathrm{N}=37\end{array}$ & $8(22)$ & $7(19)$ & $7(19)$ & $2(5)$ & $13(35)$ \\
\hline $\begin{array}{l}\text { S2 } \\
\mathrm{N}=50\end{array}$ & $14(28)$ & $11(22)$ & $16(32)$ & & $9(18)$ \\
\hline $\begin{array}{l}\text { S3 } \\
\mathrm{N}=39\end{array}$ & $7(18)$ & $8(21)$ & $10(26)$ & $5(13)$ & $9(23)$ \\
\hline $\begin{array}{l}\text { All } \\
\mathrm{N}=126\end{array}$ & $29(23)$ & $26(21)$ & $33(26)$ & $7(6)$ & $31(24)$ \\
\hline
\end{tabular}

$\mathrm{N}=$ total population

Figure in parenthesis indicates percentage value

The main occupations of the FFS members were housewife, agriculture, labor sale and then business. Among the entire sample only $24 \%$ members were studied at different level. Other than study, most of the members were involved in agriculture then labor sale, housewife and business in sample 1 (Table II). Thirty two percent respondents in the sample 2 and $26 \%$ in sample 3 were housewife though selling of labor is the important sources of income.

\section{Labour Distribution In Productive Works}

Actually productive works directly involve with production and it is well recognized that male are involved directly in productive works, where as female are involved directly in reproductive works. Productive works are those directly related with production including livestock \& poultry rearing, vegetables \& crops cultivation, marketing and labour sales. In this section results were discussed about the time spent by the female members for various productive works from different sample.

2.1 Pasture management: Comparing with all of the members among the samples, the male members of (5-12) years in sample-2 were spent maximum time (1.04 hours) for pasture. In sample-1 the members of age (5-12) years, the male members were spent more time than female and similar for sample-3. In case of sample-2, the female members of age (13-50) were spent more time than male.

2.2 Livestock \& poultry rearing: Livestock rearing is the part and parcel in the life for the rural poor people. The female members belong to (13-50) years old in sample 1 were spent more time than other male and female members among all of the members in the samples (Fig1). Poultry rearing in the areas are only for the women. The female members of different age among the samples were involved in poultry rearing more than male. Among the sample families, the female members in sample 3 were spent more time than other member's (Fig 2). 


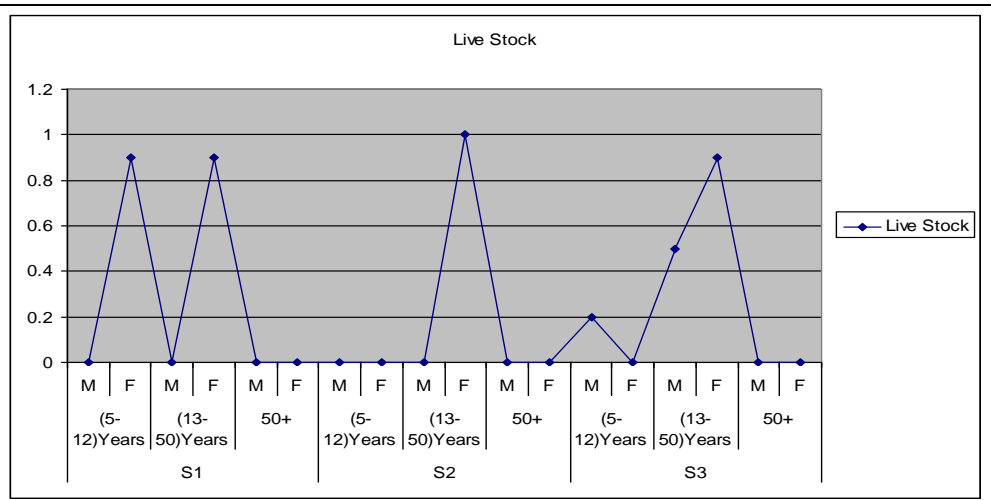

Figure 1 Average time spend for livestock rearing

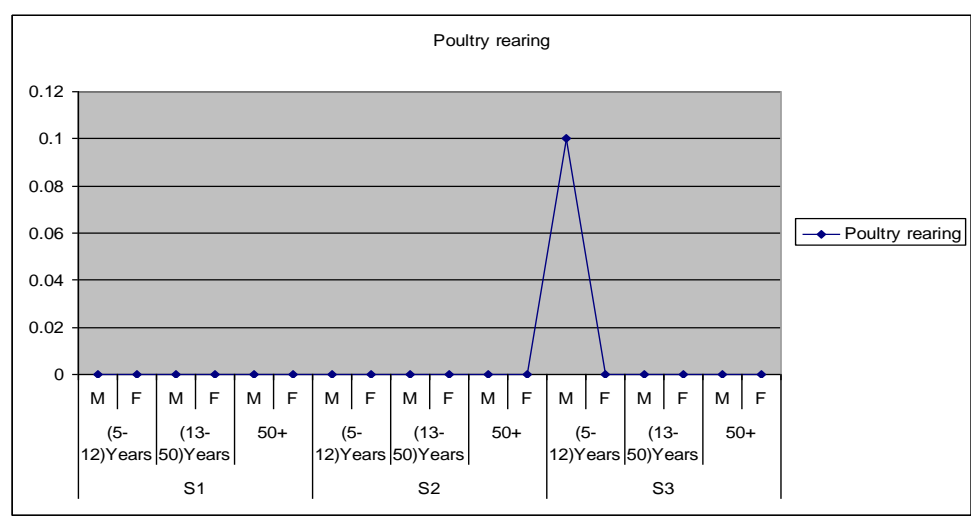

Figure 2 Average time spend for poultry rearing

2.3 Vegetables \& crop production: The male members between (13-50) years old in sample1 were spent more time ( 0.89 hours) than other members (both male \& female) among all of the members in the samples (Fig 3). Similarly the female members of age (13-50) years in sample 1 were spent more time than other female members.

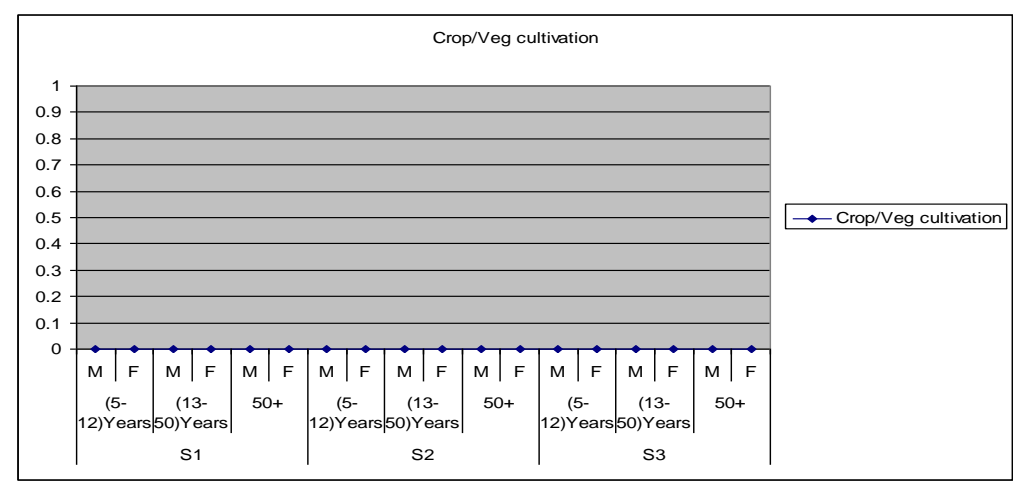

Figure 3 Average time spend for crops and vegetable cultivation

2.4 Marketing of the produces: Mainly market and marketing were handled by the male members among the samples; the female members in sample 2 were spent ( 0.10 hour) for marketing only. The maximum time (1.79 hours) were spent for marketing by the male members of age (13-50 yrs) in sample 1.

2.5 Labour sale: Labour sale is the backbone for rural poor people. The male members of age (13-50) years from sample 2 were spent maximum time (5.70 hours) for labour sale in a day then sample 3 and sample 1 . The female members of age (13-50) years from both sample (1\&2) were spent more time for labour sale (Fig 4). 


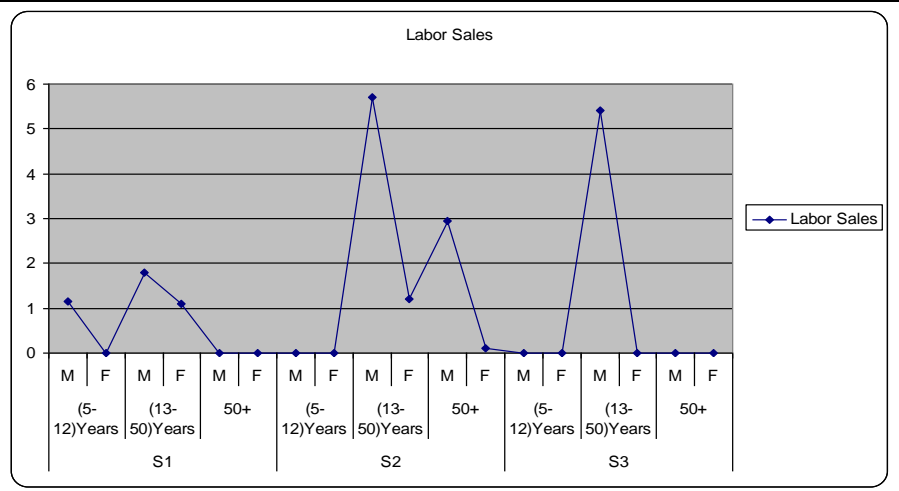

Figure 4 Average time spend for labour sale

\section{Labour Distribution In Reproductive Works}

3.1 Fire wood/fuel collection: The maximum time (1.48 hours) were spent for fire wood collection by the female members of age (13-50) years in sample-3, then sample-1 and sample-2. The male members of age (1350) were spent little time for fire wood collection among the samples. In case of sample-1, the male members of age (5-12) years were spent more time than female members (Fig 5).

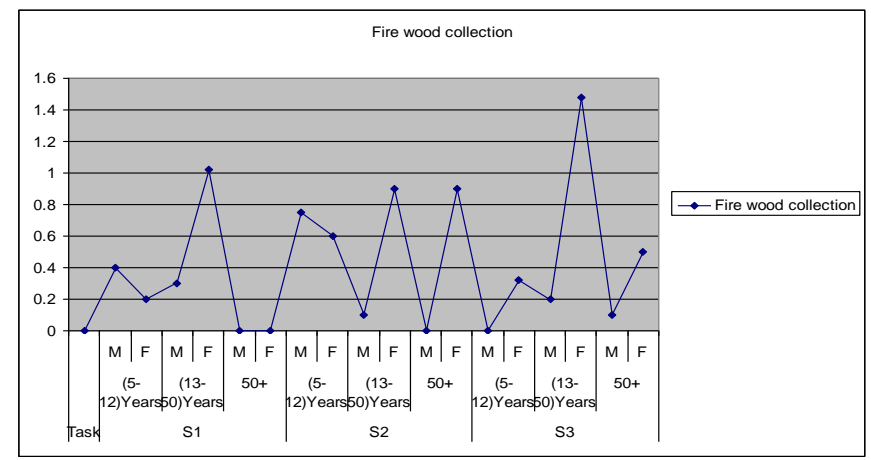

Figure 5 Average time spend for fire wood collection

3.2 Home maintenance: In sample-2, the female members of age (13-50) years were spent more time $(1.45$ hours) than other members and as well as among the samples. The male members among the sample were played minimum role in reproductive works (Fig-2b). Only the female members of age (5-12) years were assisted their mother for home maintenance.

3.3 Food preparation/cooking food: The female members of age (13-50) years were spent more time than male members. The female members of age (5-12) years were also assisted their mothers in cooking food (Fig 6). The male members among the samples were played negligible role in cooking food. But in case of members (both male and female age of 5-12 years) were spent few time for help in cooking food.

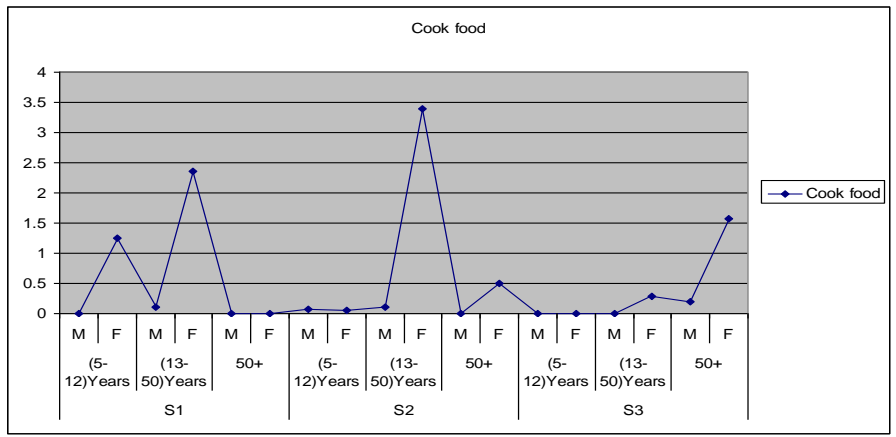

Figure 6 Time spend for cooking food

3.4 Child rearing: Children rearing is the another vital issues in our society. Mostly female takes part in child rearing rather than male. Fig 7 showed that the female members of age (13-50) years were spent more time than 
female members as well as among the samples. Among the samples, the male members also spent their time for children rearing occasionally.

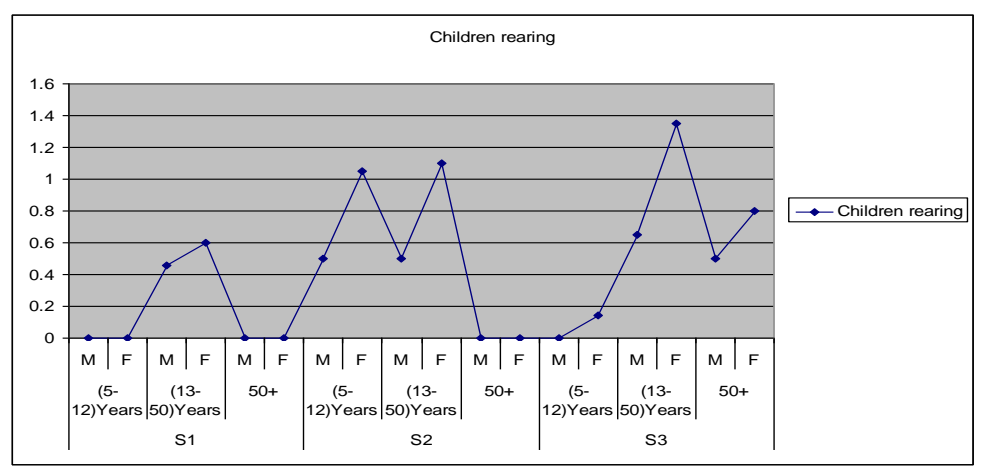

Figure 7 Average time spend for rearing the child

\section{Labour Distribution In Community Works}

4.1 Youth activities: Mostly this activity was performed by the male members solely in the family as well as among the samples. The female member never spent time for such type of activities. The female members (1350 ) years old in sample 1 , were spent little time ( 0.12 hours) in organizing youth activities.

4.2 Organizing meeting: The male members (13-50) years old in sample 2, were spent more time (1 hour) in organizing meeting than other members among the samples. Comparatively female members among the sample were spent same time for organizing meeting.

4.3 Participation in sports activities: The male members within the age (5-12) years in sample 3 were spent more time (1.64 hours) for playing than female members. Only the male members age between 13 to 50 years in sample 2 were spent time ( 0.40 hour) for play. The members (both male \& female) in all age were involved in different productive and reproductive works.

\section{Role Of Women In Family Decision Making Process}

Women are disadvantaged in many ways, they are almost always relatively poor, and they are weak in land rights, weak in political voice and poor access to benefit such as extension activities and credit. They work rarely on land which they own, they may not have decision making rights over land use. They work mostly as unpaid maid servants. A third of the world's households are headed by women, but these households tend to be among the world's poorest households.

Table III: Role of women in family decision making process

\begin{tabular}{|c|l|l|l|l|l|l|}
\hline sample & \multicolumn{3}{l}{$\begin{array}{l}\text { Before joining into SHABGE-DFID } \\
\text { Project }\end{array}$} & \multicolumn{2}{l}{$\begin{array}{l}\text { After joining into SHABGE-DFID } \\
\text { Project }\end{array}$} \\
\hline & Male & Female & Jointly & Male & Female & Jointly \\
\hline S1 N=10 & $7(70)$ & $1(10)$ & $2(20)$ & $4(40)$ & $1(10)$ & $5(50)$ \\
\hline S2 N=10 & $7(70)$ & & $3(30)$ & $6(60)$ & & $4(40)$ \\
\hline S3 N=10 & $6(60)$ & & $4(40)$ & $5(50)$ & & $5(50)$ \\
\hline All N=30 & $20(67)$ & $1(3.33)$ & $9(30)$ & $15(50)$ & $1(3)$ & $14(47)$ \\
\hline
\end{tabular}

$\mathrm{N}=$ total population

Figure in parenthesis indicates percentage value

Before joining into the SHABGE-DFID Project, 70\% male from sample $1 \& 2$ and $60 \%$ from sample 3 were took part in decision making process alone. On an average 67\% male, $3 \%$ women and $30 \%$ jointly take part in family decision making process (Table III). Corresponding figure on an average 50\% male, $3 \%$ women and $47 \%$ jointly take part in family decision making process after joining into the SHABGE-DFID Project due to creation of awareness and exposure of women in the society. In the sample-1, they take decision by discussing the subject matter among the family members. 
Intra Household Labour Distribution and Role of Women In Family Decision Making Process

Table IV: workload for women

\begin{tabular}{|l|l|l|l|l|l|c|}
\hline Sample & \multicolumn{4}{|l|}{ Workload increased } & \multicolumn{4}{l|}{ Means of increased workload management } \\
\hline & Yes & no & Own & $\begin{array}{l}\text { Help by } \\
\text { children }\end{array}$ & Husband & $\begin{array}{l}\text { Other } \\
\text { members }\end{array}$ \\
\hline S1 N=10 & $10(100)$ & & $10(100)$ & $4(40)$ & $10(100)$ & \\
\hline S2 N=10 & $10(100)$ & & $10(100)$ & $2(20)$ & $10(100)$ & $6(60)$ \\
\hline S3 N=10 & $10(100)$ & & $10(100)$ & $3(30)$ & $10(100)$ & $5(50)$ \\
\hline All N=30 & $30(100)$ & & $30(100)$ & $9(30)$ & $30(100)$ & $11(37)$ \\
\hline
\end{tabular}

$\mathrm{N}=$ total population

Figure in parenthesis indicates percentage value.

$100 \%$ respondents opined that workload increased due to joining into SHABGE-DFID project. They were managed it by taking help from other members. In sample 1, 40\% children and husband were helped in managing extra work load. On an average 37\% among sample took help from their children and other members and 30\% took help from husband only (Table IV). Several types of work increased likely attending in the session, study plot management etc. Several activities were hampered due to joining into SHABGE-DFID project; such activities include coking food, child care, labor sale, home management, poultry rearing \& livestock rearing. They were managed these workload by taking help from children $\&$ husband (in case of sample-1). In addition they are managing it by taking help from other members (Sample $2 \& 3$ ).

\section{Discussion}

Owing of economic resources is likely to restrict women's economic choices more than men's. Lesser purchasing power renders to lesser decision making power. In developing countries, the laws of inheritance and ownership generally disfavor women more than in developed countries, which may be a significant factor affecting the financial resources women have at their disposal. At the political level women also have less voice. Another important decision making power with economic implications concerns the power to decide on one's own body, sexuality and the number of children. Particularly in the study areas, the customs and norms tend to restrict the choices women are able to make in this respect.

Nieves (1981) has pointed out, this is often not very helpful to the women themselves, who have no choice about whether to work or not. For women in low-income families the issue is, precisely, how to balance work with their child-care responsibilities.

Women care for poultry and livestock. Yet women's contribution to agricultural and household production receives less recognition than their domestic and child-rearing chores which are economic tasks in our view (Kabir et al 1977).

The participation of men, women and children in a family is so interdependent that they support each other in everyday life in a large number of social, productive and economic activities (Hussain et al 1988). The SHABGE-DFID Project were tried to focus on empowering women by recruiting more female participants. Result showed that no female members were involved in marketing.. The female members' age between (13-50) years in the sample 1 were spent more time for various works than other samples. In sample 3 , the female members were spent less time (7.05 hours) for various works. Men and women play different role in the society, but their relations do not make a sense of a gender division. In the single family male and female members both were engaged in productive works. On average male members were spent one and half hours more than female members in the productive works. In case of sample $1 \& 2$, female members were spent little time than male in productive works.

In case of reproductive works, the female members in sample 2 were spent more times (6.85 hours) than other members of the samples. There was no vital role of the male members in reproductive works among the samples. Since women are usually subordinated or suppressed by men, the women needs should not be in isolation, but in the context of the gender relations.

In the terms of the "Gender and Development" literature (Moser 1993) empowerment is the equivalent of meeting women strategic gender needs. Development process are gendered and this should be taken into account in the planning and execution all of development interventions. Gender analysis and gender planning have been developed as powerful tools for this purpose. Moser (1993) distinguishes women's strategic and practical needs.

Women were weak in family decision making process before joining in SHABGE-DFID Project. After joining in SHABGE-DFID project, 50\% female from sample-1 \& 2 were took part in family decision making process actively. This indicates that they are playing active role in combined family decision making process. Dwyer (1993) has pointed out that women's allocational priorities are often geared toward survival strategies, while men's priorities may focus on mobility 
Intra Household Labour Distribution and Role of Women In Family Decision Making Process

The workload of female also increased due to joining into SHABGE-DFID project. They were managing it by taking extra load and with the support from other family members including children and husband (In case of sample 1) and with the help from other family members including father and mother (sample $1 \& 2$ ).

\section{Conclusion And Recommendation}

Considering rural income-generating activities including postharvest activities, cow fattening and milking, goat farming, backyard poultry rearing, pisciculture, agriculture, horticulture, food processing, cane and bamboo works, silk reeling, handloom, garment making, fish net making, coir production, and handicrafts women are playing great role in fostering the works.

Rural women play a major role in managing both household and natural resources including soil, water, forests, and energy. Their tasks in agriculture, forestry, and animal husbandry as well as in the household make them daily managers of the living environment.

It is widespread that the women have worked long hours in a day especially for reproductive works and social works. The gender aspect in a way has seen both a strong point in the SHABGE-DFID project. It has been strong in the sense that the project has addressed women's and their family needs in a relevant way. In a view of the fact that the project is about homestead gardening, this is traditionally women's domain. It is palpable that gender is mentioned in the project's objectives and log frame. In a sense the project has actually reinforced the prevalent gender division of labor.

It is recommended to carry out same type of study or in-depth study after completion of the project to assess the role of women in family decision making process and control over household resources.

\section{Reference}

[1.] Afsar, Rita. 1997. Onus of Poverty on Women in the Poorer Settlements of Dhaka City, Women

[2.] and Poverty. Women for Women Research and Study Group, Dhaka.

[3.] Bangladesh Bureau of Statistics (BBS). 1996. The Household Expenditure Survey, 1991-92. Dhaka.

[4.] Dwyer DH (1993). Women and income in the third world: implications for policy. Population Council International Programs Working Paper no. 18. New York: Population Council..

[5.] Hussain M S, Abedin M Z, Quddus M A, Hossain S M M, Banu T Ara and Ahmed D 1988 Women's contribution to homestead agricultural production systems in Bangladesh, Published in Bangladesh Academy for Rural Development, pp307

[6.] Islam S 1977 Women, Education and Development in Bangladesh; A few reflections, Role of women in Socio-economic development in Bangladesh-Proceedings of a Seminar, Bangladesh Economic Association Dhaka, March, 1977, pp121-131

[7.] Kabeer, Naila. 1994. Reversed Realities and Gender Hierarchies, in Development Thought.

[8.] London: Verso.

[9.] Kabir K, Abed A and Chen M 1977 Rural women in Bangladesh: Exploding some myths. Role of Women in Socio-economic development in Bangladesh. Proceedings of a Seminar, Bangladesh Economic Association Dhaka, March, 1977, pp72-79

[10.] Ministry of Women and Children Affairs 1997. National Action Plan for Implementation of Beijing Platform for Action.

[11.] Moser,C. 1993. Gender Planning and Development. Theory, Practice and Training, London, Routledge

[12.] Nieves I 1981 A balancing act: strategies to cope with work and motherhood in developing countries. Paper prepared for roundtable conference on The interface between poor women's nurturing and productive roles, International Center for Research on Women, Washington, DC, 1981.

[13.] United Nations Development Programme. 1996. Report on Human Development in Bangladesh.

[14.] World Bank. 1998. Partnership in Development: The World Bank Assistance to Bangladesh.

[15.] Dhaka Office: World Bank. 